Original Research Paper

\title{
Antiphrasis-Based Comparative Constructional Idioms in Spanish
}

\author{
Carmen Mellado Blanco \\ Faculty of Philology, University of Santiago de Compostela, Santiago de Compostela, Spain
}

Article history

Received: 07-05-2015

Revised: 01-06-2015

Accepted: 01-06-2015

\begin{abstract}
The aim of this study is to show the constructional character of the antiphrasis-based comparative structures in Spanish [SUBJ $J_{\text {[anaph] }} \mathrm{V}_{\text {TENER }}$ de $\mathrm{S} 1$ comollo que yo de $\mathrm{S} 2]$ and [ $\mathrm{SUBJ}_{[\text {anaph }]} \mathrm{V}_{[\mathrm{COGN}]}$ de $\mathrm{S} 1$ como/lo que yo de S2], respectively with the referential meaning 'not to be S1' and 'to not know/understand absolutely anything about $\mathrm{S} 1$ ' and the pragmatic meaning disagreement/criticism. These schemata in Spanish have not been studied previously, either from the perspective of phraseology (in terms of their character as idiomatic schemata) or that of Construction Grammar (looking at their value as constructional idioms). Hence, this study has a double aim: on the one hand to fill a gap in Spanish phraseological research, exploring in detail the value of these structures in terms of schematicity and as constructional idioms and on the other to establish a unifying bridge between Spanish phraseology and Construction Grammar. For the study a corpus has been compiled of 435 occurrences of the construction $\left[\mathrm{SUBJ}_{\text {[anaph] }} \mathrm{V}_{\text {TENER }}\right.$ de $\mathrm{S} 1$ como/lo que yo de $\mathrm{S} 2$ ] and 240 occurrences of the construction [SUBJ $\mathrm{S}_{[a n a p h]}$ $\mathrm{V}_{\text {[COGN] }}$ de $\mathrm{S} 1$ como/lo que yo de $\left.\mathrm{S} 2\right]$, these drawn either from the CREA corpus or from the Internet/Google using the Webcorp tool.
\end{abstract}

Keywords: Constructional Grammar, Spanish Comparative Idioms, Antiphrasis, Constructional Idioms

\section{Introduction}

\section{Constructional Idioms: Definition}

For the present study ${ }^{1}$ we take as a starting point Goldberg's (2006: 215) definition of "constructions" as "learned pairings of form with semantic and discourse function, including morphemes or words, idioms, partially lexically filled and fully general phrasal patterns". Thus, with the sentence "Diner: Waiter, what's this fly doing in my soup?", according to Kay and Fillmore (1999), the underlying construction is [What's $\mathrm{X}$ doing $\mathrm{Y}$ ?].

Within constructions, we will focus on the "partially lexically filled phrasal patterns", or "constructional idioms", to use the terminology of Taylor (2014: 11), who defines them as "patterns (of varying degrees of

\footnotetext{
${ }^{1}$ This study emerged as part of the research project FFI201345769-P: Combinaciones fraseológicas del alemán de estructura [Prep. + Sust.]: patrones sintagmáticos, descripción lexicográfica y correspondencias en español, partially funded by FEDER grants and directed by me at the University of Santiago de Compostela.
}

productivity and schematicity) for the formation of expressions, but whose syntactic, semantic, pragmatic and even phonological properties cannot be derived from general principles, whether universal or language-specific" (see also Dobrovol'skij, 2011; 2012; Mellado Blanco, 2015a; 2015b). According to Fischer (2006), constructional idioms are pairs of form and content, whose meaning "sich nicht aus den Bedeutungen seiner Teile ergibt", that is, is not the result of the sum of the meanings of the two constituents (cf Staffeldt, 2011: 132; Stathi, 2011: 149). Some examples from Spanish are:

- [DET $_{[\mathrm{EL}]} \mathrm{S} 1 / \mathrm{ADJ} 1_{\mathrm{sg}}$ de $\left.\mathrm{DET}_{[\mathrm{LOS}]} \mathrm{N} 1 / \mathrm{ADJ} 1_{\mathrm{pl}}\right]:$ el templo de los templos (Eng. the temple of temples, i.e., a very important temple from the point of view of the speaker)

- $\quad$ [TODO DET $\left.\mathrm{DUNO}_{[\mathrm{NO}} \mathrm{N}\right]$ : toda una obra, todo un detalle (Eng. all a work, all a detail, i.e., a very important work/detail to the speaker)

- $\quad$ [N1 con N1]: puerta con puerta, pared con pared (Eng. door with door, wall with wall, i.e., cheek by jowel) 
- $\quad$ no $\mathrm{SER}$ de $\left.\mathrm{V}_{[\mathrm{INF}]} / \mathrm{N}\right]$ : No soy de comer mucho (Eng. I'm not of eating much, i.e., I'm not one for eating much)

- $\quad$ Y venga a $\left.\mathrm{V}_{[\mathrm{INF}]}\right]$ : Y venga a comer/hablar/... (Eng. And come to eat/speak/..., i.e., he/she eats/speaks/... again and again)

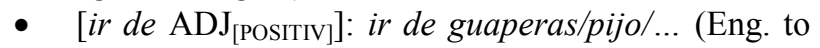
go around beautiful/brattish/..., i.e., to boast to be very beautiful/brattish/...)

The term "constructional idiom" (Taylor, 2014) is to a greater or lesser degree the same phenomenon as the German terms "modellierte Bildungen" (Černyševa, 1975), "phraseologisierte syntaktische Muster" (Eckert, 1979), "Phraseoschablonen" (Fleischer, 1997: 130-134, Donalies, 2009), "typische grammatisch-stilistische Konstruktionen", "idiomatische Konstruktionsmuster" (Finkbeiner, 2008: 218), "Modellbildungen" (Burger, 2010: 45), "syntaktische Prägungen" (Feilke, 1994), "semantisch-strukturelle Modelle" (Dobrovol'skij, 1988; Hundt, 2005), "syntaktische Ausdrucksmodelle mit primär pragmatischer Prägung: Topik-Muster" (Feilke, 1996: 242) and the English terms "lexically open idioms" (Fillmore et al., 1988) and "linguistic schemata" (Van Lancker Sidtis et al., 2012).

What seems interesting to us is the focus on these structures from German phraseology (cf Häusermann, 1977; Fleischer, 1997; Burger, 2010) in terms of Construction Grammar because, in contrast to Spanish phraseology, the German school has emphasised the link that exists between the syntactic structure and the global meaning of the structure (cf Steyer, 2013). Such an approach is in keeping with the general principles of Construction Grammar (cf Goldberg, 1995), according to which constructions are "learned pairings of form with semantic and discourse function" (Goldberg, 2006: 215). Thus, Häusermann (1977: 30), following the Russian Germanist Černyševa (1975: 64-69), considers the "Modellbildungen" (for us constructional idioms) to be fixed syntactic schemata within determined lexical frames. These schemata are endowed with a "pre-established semantic nuance" and with some auto semantic components which are more or less lexically free. In the words of Burger (2010), the "Modellbildungen" "sind nach einem Strukturschema gebildet, dem eine konstante semantische Interpretation zugeordnet ist und dessen autosemantische Komponenten lexikalisch (mehr oder weniger) frei besetztbar sind"2. This definition coincides broadly with Dobrovol'skij's (2011: 114) definition of the "Phrasem-Konstruktionen".

\footnotetext{
2 "[They] are formed in keeping with a structural schema to which a constant semantic interpretation corresponds and whose autosemantic components present a variable degree of lexical fixedness" (our translation).
}

"Phrasem-Konstruktionen" (constructional idioms) have a lexical meaning when together and some elements of the syntactic structure are lexically fixed, while other elements are free slots, "die gefüllt werden müssen, indem ihre Besetzung lexikalisch frei ist und nur bestimmten semantischen Restriktionen unterliegt",3. In accordance with Deppermann's (2006: 48) classification of these constructions according to the degree of structural schematicity and lexical specificity of the slots, constructional idioms would be type 2, that is, "lexikalisch teilspezifierte Konstruktionen" ("partially lexically filled phrasal patterns" in the terminology of Goldberg, 2006: 215).

Considering the above definitions, in the present study we conceive of constructional idioms as:

(1) Pre-established syntactic schemata endowed with a unitary meaning, this being more or less abstract depending on the construction.

(2) Some of the constituents of the constructions are fixed autosemantic or semisemantic lexemes and others are not lexically specified (free slots).

(3) The free slots renew themselves in the discourse through lexemes that correspond to a predetermined semantic profile, that is, they are in general not totally free. The degree of semantic restriction to which the free slots are submitted is variable according to each construction.

\section{(4) They are endowed with a specific pragmatic meaning ${ }^{4}$.}

In relation to point (3), we should add that it is probable that some of the slots which start as free become fossilised and lexicalised, through which constructional idioms would become close to idioms. On the scale from the lexical pole, represented by idioms, to the grammatical pole, represented by free syntactic structures, constructional idioms would be located at an intermediate level, with the possibility of rising as far as the extreme of the lexical pole, adopting thus the form of idioms. Such would be the case with the Spanish idiom trabajar codo con codo (to work elbow to elbow) with the idiomatic meaning 'to work closely together; to work side by side', developed from the constructional idiom [V N1 con N1]. Other examples are: vivir puerta con puerta/pared con pared/casa con casa (to live door by door/wall by

\footnotetext{
${ }^{3}$ [W] hich should be filled, their saturation being lexically free and only subject to certain semantic restrictions (our translation).

${ }^{4}$ Following Van Lancker et al. (2012: 91), "Schemata have the advantage of communicating special nuances and connotation".
} 
wall/house by house: 'to live right next to'). Here the saturation of the slot $\mathrm{V}$ has been produced through the fixed lexeme trabajar (to work) and the saturation of slot N1 through the lexeme codo (elbow) $)^{5}$.

Finally, it is interesting to note, in keeping with point (3), that constructional idioms should not be confused with the lexical variants of an idiom. For example Spanish no importar a alguien un bledo/un pimiento/una mierda/un cojón/una mandanga (it does not bother someone a bit/a pepper/a shit/a testicle/a waste of time), in which the nouns bledo, pimiento, mierda, cojón, mandanga form part of a numerically limited list and also do not give the idiom any particularised lexical meaning. All variants here mean the same thing: 'no importar a alguien absolutamente nada' (to be of absolutely no importance to anyone). On the contrary, in constructional idioms the slots are not numerically limited, cannot be inventoried (see Mura, 2014: 280) and their lexical renewal in discourse brings with it the fixing of the general meaning of the construction. Thus, in the constructional idiom [ADJ $1_{\text {[Sing] }}$ entre los $\left.\mathrm{ADJ} 1_{\text {[Plural] }}\right]$, the concrete meaning of the utterance varies depending on ADJ1: guapo entre los guapos ('muy guapo') (goodlooking among the good-looking ones, i.e., very handsome), listo entre los listos ('muy listo') (clever among the clever ones, i.e., very clever).

In terms of Spanish phraseology, idiomatic schemata have been studied more from a morphological and syntactic perspective than a semantic and pragmatic one ${ }^{6}$. In Spanish, these structures have been given the names "esquemas fraseológicos" ("phraseological schemata") (Zuluaga, 1980: 159-160; 110-113), "esquemas sintácticos" ("syntactic schemata") (GarcíaPage Sánchez, 2007: 124ff, 2008a), or "locuciones de casillas vacías" (Montoro del Arco, 2008) for whom the "casillas vacías" (slots) are discoursively saturated by

\footnotetext{
${ }^{5}$ In general, above all in cases of proverbs, the contrary case is more typical: that the structure of a proverb becomes productive and generates a constructional idiom with free slots. It occurred thus in Spanish with the proverb Dime con quién andas y te diré quién eres (Tell me who you are going about with, and I'll tell you who you are), converted to the constructional idiom [DimeRELATIVE CLAUSEy te diré quién eres], with the global meaning 'through the quality or activity of a person denoted in the relative clause it is possible to define the person'.

${ }^{6}$ A pragmatic approach can be seen in recent studies, but only in relation to echoing constructions, into Spanish (e.g. the construction of REJECTION [qué X ni qué narices (That $\mathrm{X}$ not (even) what the hell $\rightarrow$ Not a chance!)] in Olza Moreno, 2011), and Spanish and Italian under the term "esquemas sintácticos fraseológicos pragmáticos" ("pragmatic-phraseological syntactic schemata", see Zamora Muñoz, 2003, 2014) or "esquemas fraseológicos" ("phraseological schemata", see Mura, 2012, 2014; Mura/Ruiz Gurillo, 2010). For the lack of interest for the Construction Grammar in the Romance languages, see De Knop/Mollica (2013: 9-10).

${ }^{7}$ Montoro del Arco (2008: 137) takes the term "locuciones de casillas vacías" from Zuluaga (1980: 108-109).
}

elements of a "categoría gramatical plena" (full grammatical category) (Montoro del Arco, 2008: 137). Montoro makes the following categorisation of "locuciones con casillas vacías" ("idioms with free slots"):

- Nominal idioms with free slots: [S] al canto; el/un [S] de marras

- Adjectival idioms with free slots: [Adj] como PRON solo

- Pronominal idioms with free slots: algún [S] que otro

- Sentence idioms with free slots: ¡Qué [S] ni qué carajo/narices!

- Comparaciones fraseológicas (comparative idioms): vender $\left[\mathrm{S}_{\mathrm{PL}}\right]$ como churros, caer $\left[\mathrm{S}_{\mathrm{PL}}\right]$ como moscas ${ }^{8}$

\section{The Comparative Constructional Idioms [SUBJ $\mathrm{S}_{\text {[anaph] }} \mathrm{V}_{\mathrm{TENER}}$ de $\mathrm{S} 1$ como/lo que yo de $\mathrm{S2}]$ and [SUBJ $\mathrm{Sanaph]}_{\text {[COGN] }}$ de $\mathrm{S} 1$ como/lo que yo de $\mathrm{S2}]$}

\section{Corpus}

During the process of writing our dictionary Idiomatik Deutsch-Spanisch (Schemann et al., 2013), which contains more than 35,000 multi-word lexical units, we found some comparative idioms in German that had as an equivalent in Spanish not a comparative idiom but a constructional idiom. These were the idioms von etw. so viel verstehen wie der Hahn vom Eierlegen and von etw. so viel verstehen wie die Kuh vom Sonntag ${ }^{9}$ (not to know the first thing about sth.), which in Spanish correspond to the comparative constructional idiom [SUBJ ${ }_{[a n a p h]} \mathrm{V}_{\text {[COGN] }}$ de $\mathrm{S} 1$ como/lo que yo de $\left.\mathrm{S} 2\right]$.

This was the point of departure for the compilation of a corpus of real examples of comparative constructional idioms [ $\mathrm{SUBJ}_{[\text {anaph] }} \mathrm{V}_{[\mathrm{COGN}]}$ de $\mathrm{S} 1$ como/lo que yo de $\left.\mathrm{S} 2\right]$ and $\left[\mathrm{SUBJ}_{\text {[anaph] }} \mathrm{V}_{\mathrm{TENER}}\right.$ de $\mathrm{S} 1$ como/lo que yo de $\left.\mathrm{S} 2\right]$. Given that these constructions were eminently colloquial and very much part of the oral language, in both the CREA and Mark Davies corpora very few occurrences were found (11 in CREA, 1 in Mark Davies). For this reason it was necessary for us to use the Internet/Google through Webcorp ${ }^{10}$ in searching for examples of use in

\footnotetext{
${ }^{8}$ In Montoro del Arco's classification, comparative idioms are included as part of the "locuciones de casillas vacías": the slots in the discourse are the comparanda. Thus, in a sentence such as Los soldados caían como moscas (The soldiers fell like flies), the subject los soldados (the soldiers), which is the comparandum, has by necessity to be in the plural because in this way it elicits the grammatical number of the comparatum.

9 The constructional character of these German idioms is explored in Mellado Blanco (2015b). Antecedents of this study can be found in Mellado Blanco (2012).

${ }^{10}$ The practice of using the Internet/Google as a large corpus when searching for terms that reflect "conceptual orality" (a concept introduced by Koch/Österreicher, 1985) is common not only in phraseology and the study of proverbs (cf
} 
forums, chatrooms and online news media. For the constructional idiom [SUBJ $]_{[a n a p h]} \mathrm{V}_{\mathrm{TENER}}$ de $\mathrm{S} 1$ como/lo que yo de $\mathrm{S} 2] 435$ occurrences were thus collected and for [SUBJ $\mathrm{S}_{\text {[anaph] }} \mathrm{V}_{[\mathrm{COGN}]}$ de $\mathrm{S} 1$ como/lo que yo de $\left.\mathrm{S} 2\right]$ a total of $240^{11}$. Our objective was not to be exhaustive with respect to the composition of the corpus, but rather to collect enough examples to make feasible a study of the semantics and pragmatics of these constructional idioms.

\section{Antiphrasis-Based Comparative Constructional Idioms: A Type of Comparative Constructional Idioms}

As explained in Mellado Blanco (2012), we believe that comparative idioms (for example más viejo que Matusalén, dormir como un lirón (older than Methuselah, to sleep like a dormouse) underlie comparative

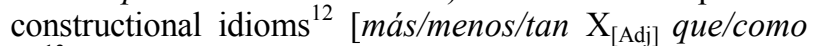
$\mathrm{Z}]^{13}$ and $\left[\mathrm{X}_{[\mathrm{Verb}]}\right.$ más/menos/tanto que/como $\left.\mathrm{Z}\right]$, both being endowed with a pragmatic meaning of intensification (cf González Rey, 2000, Penadés Martínez, 2010). In comparative constructional idioms, the free slots are the tertium comparationis (adjective $\mathrm{X}_{[\text {Adj] }}$ or verb $\mathrm{X}_{[\mathrm{Verb}]}$ ) and the comparatum is the slot $\mathrm{Z}$. The fixed elements on which the construction pivots are adverbs (más, menos, tan, tanto) and the comparative nexus como and que.

The antiphrasis-based comparative constructional idioms are a structural type of comparative constructional idioms and hence share with these the following characteristics:

(1) Comparative constructional idioms and comparative idioms present an overall intensifying meaning, a feature which differentiates them from non-

Kleinberger, 2006; Konecny, 2010; Torrent, 2013), but more generally in the fields of linguistics which deal with oral language (cf Hummel, 2012 on discourse markers).

${ }^{11}$ The search for occurrences of the construction $\left[\mathrm{SUBJ}_{[\mathrm{anahh}]}\right.$ $\mathrm{V}_{\text {TENER }}$ de $\mathrm{S} 1$ como/lo que yo de $\mathrm{S} 2$ ] used the following sequences: (1) "como yo de", (2) "lo que yo de ", (3) "tiene de" / "como yo de". For the construction [SUBJ $]_{[\text {anaph] }} \mathrm{V}_{\text {[COGN] }} d e \mathrm{~S} 1$ como/lo que yo de $\mathrm{S} 2]$, the search sequences were: (1) "como yo de", (2) "lo que yo de", (3) "sabe de" / "como yo de", (4) "entiende de" / "como yo de", (5) "sabe de" / "lo que yo de", (6)"entiende de" / "lo que yo de". As can be seen here, the analysis of the construction is limited to cases in which the subject is in the third person.

${ }^{12}$ We can find an antecedent of this idea in Hundt (2005: 128), who talks about comparative idioms as "strukturellsemantische Modelle", that is, semantic-structural models that are reproduced by the speaker as syntactic schemata.

${ }^{13}$ The comparative constructional idiom [más/menos/tan $\mathrm{X}_{[\mathrm{Adj}]}$ que/como Z] can present, among others, the following substructures: [más $\mathrm{X}_{\text {[Adj] }}$ que $\mathrm{Z}$ ] (más rojo que un tomate) (redder than a tomato $\rightarrow$ very red), [más $\left.\mathrm{X}_{\text {[Sust] }} q u e \mathrm{Z}\right]$ (tener más años que Matusalén) (to have more years than Methuselah $\rightarrow$ to be very old), [tan $\mathrm{X}_{\text {[Adj] }}$ como Z] (tan blanco como la nieve) (as white as snow $\rightarrow$ very white). idiomatic comparative phrases, in which a real comparison is made between two entities of the extralinguistic reality (thus, in the sentence El libro de Juan es más gordo que el de Pedro (Juan's book is thicker than Pedro's) a real comparison is made between el libro de Juan (Juan's book) and el libro de Pedro (Pedro's book). By contrast, comparative idioms do not give information on the comparison between objects, but instead serve basically as a means of intensifying a quality (see GarcíaPage Sánchez, 2008a: 318; Albelda Marco, 2007) ${ }^{14}$, expressing thus the maximum degree of the quality of a subject. In antiphrasis-based comparative constructional idioms something similar happens: These also serve to reinforce the denotative meaning, in this case the absence of a quality and not to establish a real comparison.

(2) Unlike the comparatum of non idiomatic comparative phrases, the comparatum of comparative idioms lacks referencial meaning and only alludes to a quality represented by the comparatum in the maximum degree $^{15}$. In the words of García-Page Sánchez (2008a: 323), "los representantes típicos están disponibles previamente en el código como simples piezas léxicas y sólo entran en acción cuando se requiere intensificar en grado sumo la característica a la que están culturamente asociados"16. This also occurs in antiphrasis-based comparative constructional idioms, the comparatum of which lacks real referential value, unlike analogous comparative structures ${ }^{17}$, in which a comparison with real

14 For Albelda Marco (2007: 47), adjectival comparative idioms are a proceedure of intensification of the utterance at the lexical level (2007: 58), by being multi-word expressions, the sytactic level, given that the comparative structure is itself intensifying (see Albelda Marco, 2007: 71), and the semantic level, in that similes and comparisons are a type of trope (Albelda Marco, 2007: 77).

${ }^{15}$ This explains why in stereotyped comparisons inversions of the terms of the comparison are not possible, as in free comparisons: El libro de Juan es más gordo que el de Pedro $\rightarrow$ El libro de Pedro es menos gordo que el de Juan (Juan's book is thicker than Pedro's $\rightarrow$ Pedro's book is thicker than Juan's); Juan es más lento que una tortuga $\rightarrow *$ *na tortuga es más lenta que Juan (Juan is slower than a tortoise $\rightarrow * \mathrm{~A}$ tortoise is slower than Juan). In this article we use the symbol $\rightarrow$ to indicate both the literal meaning (to the left of the arrow) and the figurative meaning (to the right of the arrow).

16 "'[T]ypical representatives are previously available in the code as simple lexical parts and only come into action when an especially high intensification of the characteristic with which they are culturally associated is required" (our translation).

${ }^{17}$ In the sentence La mesa tiene de larga lo que la estantería de alta (The table has in length what the shelves have in height $\rightarrow$ The table is as long as the shelves are high), with a structure similar to that of the construction [SUBJ [anaph] $\mathrm{V}_{\text {TENER }}$ de $\mathrm{S} 1$ como/lo que yo de $\mathrm{S} 2$ ], a comparison is made between the qualities of two objects, which makes possible the reversibility of the terms of comparison: La estantería tiene de alta lo que la mesa de larga (The shelves are as high as the table is long). By contrast, in the constructional idiom such reversibility is not possible: $L a$ 
entities in the exterior world is indeed made. In the case of the constructions here, the comparatum, based on a hyperbole, possess essentially an elevated pragmatic value, not a denotative one, with the job of intensifying the negation of the quality.

(3) The constructional character of comparative idioms is given by that very comparative structure, which itself carries the pragmatic feature of the intensification of the propositional content $(\text { dictum })^{18}$. The value of the construction and its schematic character make possible the interchange of the prototypes of a quality without this having any repercussions in the idiomatic meaning (ser más feo que Picio/que Carracuca/que pegar a un padre (con un calcetín (sucio)), etc.: (to be uglier than Picio/Carracuca/than to strike a father (with a (dirty) sock)) $\rightarrow$ to be very ugly $)^{19}$. It can also happen that the same prototype (for example Carracuca) is used to intensify different qualities (ser más feo/viejo/tonto que Carracuca), in which case the comparatum undergoes a clear process of desemanticisation. This phenomenon can be observed in the lexemes astronauta (astronaut) and cura (priest) in the constructional idiom $\left[\mathrm{SUBJ}_{[\mathrm{anaph}]}\right.$ $\mathrm{V}_{\mathrm{TENER}}$ de $\mathrm{S} 1$ como/lo que yo de $\mathrm{S} 2$ ].

(4) The pragmatic meaning of intensification of the construction explains the creation of new prototypes ${ }^{20}$, in both comparative constructional idioms and antiphrasisbased comparative constructional idioms $\left[\mathrm{SUBJ}_{[\mathrm{anaph}]}\right.$ $\mathrm{V}_{\mathrm{TENER}}$ de $\mathrm{S} 1$ como/lo que yo de $\mathrm{S} 2$ ] and [SUBJ $\mathrm{S}_{\text {[anaph] }}$ $\mathrm{V}_{\text {[COGN] }}$ de $\mathrm{S} 1$ como/lo que yo de $\left.\mathrm{S} 2\right]$. In all of these, the new prototypes can become lexicalised over time.

(5) Despite the degree of schematicity and lexical abstraction of constructional idioms (cf Van Lancker Sidtis et al., 2012), it must be borne in mind that both the lexemes which fill the slot $X_{[\text {Adj] }}$ and those which fill the slot $\mathrm{Z}$ are part of a list of elements predefined conceptually (in the case of slot $X_{[\text {Adj] }}$ ) or lexically (in the case of slot $Z$ ). Thus, the concepts represented through $\mathrm{X}_{[\mathrm{Adj}]}$ tend to express negative qualities or

gentesabe debolsalo que yo de ingeniería aeroespacial $<$ http://www.rankia.com/foros/bolsa/temas/1644915-carbureseurope?page $=2308>\rightarrow *$ Yo sé de ingeniería aeroespacial lo que la gente de bolsa (People know as much about the Stock Exchange as I do about aerospace engineering $\rightarrow$ *I know about aerospace engineering as much as people know about the Stock Exchange). $<$ http://www.rankia.com/foros/bolsa/temas/1644915-carbureseurope?page $=2308>$.

${ }^{18}$ For this reason, what we have here is an indexal motivation, in that the very structure and the hyperbolic meaning of the image act as an index of the intensifying feature of its idiomatic meaning. For the term "indexal motivation"see Dobrovol'skij / Piirainen (2009) and Mellado Blanco (2013).

${ }^{19}$ Schindler (1993: 101) calls this phenomenon "conglomerates of synonyms".

${ }^{20}$ For the creative modifications of comparative idioms, see Millán (2002), <http://jamillan.com/compara.htm>. human states, as happens with the majority of idioms (see Dobrovol'skij, 1988: 39).

In the case of slot $Z$ of the comparative idiom, the limitation and specificity of $\mathrm{Z}$ is not of a conceptual type, but rather a lexical one, in that in every language there exists a pre-existing list of lexemes which function as prototypes of a given quality. Thus, in order to intensify 'blancura' (whiteness) in Spanish use is made of the lexemes nieve (snow), cal (lime), pared (wall), armiño (ermine), mármol (marble), papel (paper). In order to intensify the quality 'rojo' (red), the prototypical lexemes are tomate (tomato), pimiento (capsicum/pepper) and cangrejo (crayfish). In antiphrasis-based comparative constructional idioms, common features also exist in the lexemes that occupy slot S2 (comparatum).

Antiphrasis-based comparative constructional idioms show certain significant differences from comparative constructional idioms/comparative idioms. Among these are:

- From a lexical point of view, the fundamental difference with respect to comparative idioms is that a part of the comparatum of antiphrastic constructional idioms [SUBJ ${ }_{[a n a p h]} \mathrm{V}_{\text {TENER }}$ de $\mathrm{S} 1$ como/lo que yo de $\mathrm{S} 2]$ and $\left[\mathrm{SUBJ}_{[\text {anaph] }} \mathrm{V}_{\text {[COGN] }}\right.$ de $\mathrm{S} 1$ como/lo que yo de $\mathrm{S} 2$ ] is not represented by an external cultural stereotype and agreed on by the speakers of a linguistic community, but rather is a quality or characteristic of the particular speaker (I). This entails interesting consequences on the semantic-pragmatic level

- The subject of comparative idioms does not need to have an anaphoric value, unlike antiphrastic comparative constructional idioms, with an echoing value which replicates an utterance

- From a pragmatic point of view, antiphrastic comparative constructional idioms have an evidential epistemic value which comparative idioms lack

\section{Antiphrasis and Comparative Constructional Idioms}

The semantically motivated relation between the tertium comparationis (TC) and the comparatum of comparative idioms can, from a synchronic perspective, be totally transparent (blanco como la nieve) (white as snow $\rightarrow$ to be very white) or opaque, when the defining semantic features of the comparatum are not contained in the TC, for example between sordo (deaf) and tapia (garden wall) in the idiom estar más sordo que una tapia (to be deafer than a garden wall/to be as deaf as a post $\rightarrow$ to be very deaf) (cf Mellado Blanco, 2009; 2012). In other cases, there is an antithetical relation between the TC and the comparatum, as in the comparative idiom nadar como el plomo (to swim like lead $\rightarrow$ not to know how 
to swim), gordo como un fideo (fat like a noodle $\rightarrow$ very fat) to express negative polarity in an indirect way.

This type of antiphrasis-bases comparative idioms is known in the Hispanic world as comparaciones estereotipadas antifrásticas ("stereotyped antiphrastic comparisons") (see Ortega Ojeda, 1990: 735; Boyer, 2000; García-Page Sánchez, 2008a: 321, 2008b; Durán and Bertrán, 2005: 387; Pamies Bertrán, 2005: 474-475) and are not a common feature in languages (see Glovňa, 1992: 55). In them, the comparatum alludes to a cultural stereotype contrary to the quality or action expressed by the TC and the meaning of negation of the expression needs to be inferred from their semantic incompatibility between TC and comparatum. It is, then, an implicit negation, endowed with a high degree of expressivity through the logical contradiction between TC and comparatum.

It ought to be noted that antiphrasis does not only appear in the "comparative idioms", but in general in the different types of "phraseological units", as can be seen in the verbal idiom brillar por su ausencia (to be conspicuous by its/their absence), the conversational routine ¡No es nada! (It's nothing! $\rightarrow$ It's very much!) and the constructional idiom [iNo es + ADJ + ni nada! (It's not $+\mathrm{ADJ}+$ or anything! $\rightarrow$ It's very $+\mathrm{ADJ}$ !).Due to its proximity to irony, antiphrasis tends to be confused with this, when in reality they are two different rhetorical figures. According to the distinction made by Lausberg (1984: 85-87) and by Penadés Martínez (1999: 191), whereas irony is a rhetorical figure of thought, antiphrasis is a rhetorical figure of speech. Thus, irony is a contradiction which is understood through its intonation and only in relation to the specific communictive situation, unlike antiphrasis, which, "como figura de dicción, se revela como contrasentido mediante el contexto lingüístico inmediatamente próximo"21 (Penadés Martínez, 1999: 191), that is, through the utterance itself. This is why in the present study we use the term antiphrasis rather than irony for the constructions analysed, although both phenomena have common characteristics, such as similar intonation (see the definition of antiphrasis in Lázaro Carreter, 1971: 48) and a possible implicature of CRITICISM with respect to the content of the utterance.

Constructional idioms $\left[\mathrm{SUBJ}_{\text {[anaph] }} \mathrm{V}_{\text {TENER }}\right.$ de $\mathrm{S} 1$ como/lo que yo de $\mathrm{S} 2]$ and $\left[\mathrm{SUBJ}_{[\mathrm{anaph}]} \mathrm{V}_{\text {[COGN] }}\right.$ de $\mathrm{S} 1$ como/lo que yo de $\mathrm{S} 2$ ], which are very productive in Spanish $^{22}$, are based, like antiphrasis-based

21 [L]ike a rhetorical figure of speech, is revealed as a contradiction through the immediately following linguistic context (our translation).

${ }_{22}$ These antiphrasis-based comparative constructional idioms, very productive nowadays, have a long history in the Spanish comparative idioms (for example nadar como el plomo: to swim like lead $\rightarrow$ not to know how to swim) on an antiphrasis, hence the antiphrastic meaning of negative polarity is more complex and only achieved through a series of logical inferences, as in the following example:

- $\quad$ - De la política y la historia española Lola sabía lo que yo de marcianos, [...].(CREA, Prensa: Tiempo, 29/05/1995)

- (- Of Spanish politics and history Lola knew as much as I know about Martians, [...])

The inferences necessary to correctly decode this example are the following:

- That the speakers knows nothing about Martians.

- If Lola knew as much about Spanish politics and history as the speaker does about Martians, then Lola would know nothing about politics and history ${ }^{23}$.

In effect, the antithetical relation is not directly produced between the meaning of the lexeme in slot S1 (politics and history) and that of slot S2 (Martians), but rather between the speaker himself $(I)$ and the quality represented by the lexeme that occupies slot S2 (Martians). The lack of the quality of S2 in the $I$ (speaker) provokes, by means of the comparison, the implicit negation of the quality expressed by slot $\mathrm{S} 1$.

\section{Lexical Specificity of Slots S1 and S2 of Constructional Idioms}
The Antiphrasis-Based Comparative Constructional Idiom [SUBJ $J_{\text {[anaph] }} V_{[C O G N]}$ de S1 como/lo que yo de $S 2]$

The verbs of cognition which generally appear in this constructional idiom, with the meaning 'to not know/understand absolutely anything about S1', are saber

language. The earliest recorded in the CORDE is from 1605 , the second from 1758: [...] sé muy bien que tiene tanto de español como yo de francés (CORDE, José Francisco de Isla (1758): Historia del famoso predicador Fray Gerundio de Campazas alias Zotes) (I know well that he is as much Spanish as I am French (not at all)). In other European languages, such as German, we have also noted the existence of the antiphrasisbased comparative constructional idiom [ $\mathrm{SUBJ}_{[\mathrm{anaph}]} \mathrm{V}_{\text {[COGN] }}$ von $\mathrm{S} 1$ so viel wie ich von $\mathrm{S} 2]$ (see Mellado Blanco, 2015b).

${ }^{23}$ This chain of inferences is also given in antiphrasis-based comparative idioms, as in: parecerse A a B tanto como un huevo a una castaña: (A and B seem alike as much as an egg seems like a chestnut $\rightarrow$ A and B seem very alike) (1) an egg seems nothing at all like a chestnut, (2) thus A and B do not seen anything like each other. 
(know) and entender (understand). In terms of the lexical specificity of slots S1 and S2 in the discourse, we note a high degree of heterogeneity in their use. The lexical variation of the $\mathrm{S} 1$ is explained by its direct link to the theme of the discourse, while the lexical heterogeneity of $\mathrm{S} 2$ is related to the speaker's need to reinforce the expressivity of his message by creating new images.

Despite the lexical variety in slot $\mathrm{S} 1$, we note the recurrence of certain elements:

- Nouns which designate some kind of knowledge or understanding: politics, industry, finance, arbitrage, sport, culture, music, traffic accidents, laws, literature, the language of Shakespeare, education, cinema, the Stock Exchange, science, etc

- Nouns which designate some kind of ability or know-how: cooking, photography, manners, massages, resuscitation, electricity, personal relations, including here many names of sports: football, sailing, basketball and of languages: Spanish and sentiments: love

In addition to nouns, various proper nouns (Venezuela) and verbs (to dance) also appear in slot S1. In terms of slot S2, in Table 1 are some of the lexemes and semantic fields from the corpus examples.

From what can be seen in Table 1, slot S2 of the construction [SUBJ $\mathrm{S}_{[\text {anaph] }} \mathrm{V}_{\text {[COGN] }}$ de $\mathrm{S} 1$ como/lo que yo de $\mathrm{S} 2]$ is realised in the discourse above all by lexemes which denote knowledge which is considered to be difficult stereotypically: physics, astronomy or aerospace science, exotic languages, specific understanding of the sexual life of certain animals, etc. The effect of surprise which the varied nature of the S2 causes in the interlocutor reinforces the communicative success of the message ${ }^{24}$. With the lexical realisations of slot S2 we can note a certain tendency towards the lexicalisation of the noun física cuántica (quantum physics) (241 occurrences found on Google).

In terms of the grammatical category of S2, in the corpus we have nouns without a complement, nouns modified by a complement and verb (see Table 2).

\section{Antiphrasis-Based Comparative Constructional Idiom [SUBJ $J_{\text {[anaph] }} V_{\text {TENER }}$ de S1 como/lo que yo de $S 2]$}

As was the case with the previous construction, the lexical realisation of slots $\mathrm{S} 1$ and S2 here is very varied.

In this construction, of the referential meaning 'not to be $\mathrm{S} 1$ ', it is notable that the structure $\left[\mathrm{V}_{\text {TENER }} \mathrm{ADV}_{\text {[quantif] }}\right.$ de $\left.\mathrm{X}\right]$ on which the constructional idiom is based is already itself a

\footnotetext{
${ }^{24}$ However, it should be borne in mind that the communicative success of the utterance is linked to the pre-established patterns of the construction for the lexical saturation of slot S2: exotic languages, highly specialised scientific disciplines, etc.
}

construction $^{25}$, the quantifying comparative adverb tanto (as much) is presupposed: "Tienes tanto de novelista como yo de santo" (You have as much of novelist (in you) as I do a saint $\rightarrow$ You're as much a novelist as I am a saint). This construction has an emphasising pragmatic value and normally serves to intensify a negative quality of the subject. Thus, the sentence Juan tiene poco de listo (Juan has little of the intelligent about him) is equivalent to Juan es poco listo (Juan is not very intelligent) (litotes of Juan es torpe). Hence, in the case of $\left[\right.$ poco $\left.^{26}+\mathrm{Adj}\right]$, we have a litotes construction in which the preposition with a partitive value de (see Martínez García, 2005: 194-195) ${ }^{27}$ appears with a qualifying adjective, or with a noun with an adjectival value ${ }^{28}$. Hence, the verb tener (to have) intervenes with a relational meaning and not that of 'possessor', that is, it has an attributive value rather than a possessive one ${ }^{29}$.

The most frequent adjectives in the $\mathrm{S} 1$ of the constructional idiom [SUBJ ${ }_{[a n a p h]} \mathrm{V}_{\text {TENER }}$ de $\mathrm{S} 1$ como/lo que yo de $\mathrm{S} 2$ ] are qualitative ones of the evaluative type, as happens with the simple construction [ $\mathrm{V}_{\text {TENER }}$ $\mathrm{ADV}_{\text {[quantif] }}$ de $\left.\mathrm{X}\right]$ and they describe positive qualities of humans. Thus, they are positive evaluative adjectives, which are those which denote "una propiedad considerada pragmáticamente positiva por los miembros de una comunidad" (a property considered pragmatically positive by the members of a community) (see Sedano, 2009: 160), of the type bueno (good), inteligente (intelligent), etc. The antiphrastic construction serves specifically to create a negative polarity of the denoted quality by the adjective of slot S1. In other cases, the adjectives of $\mathrm{S} 1$ are demonymic, of the type ruso (Russian), catalán (Catalan), español (Spanish), etc.

\footnotetext{
${ }^{25}$ The constructional idiom [SUBJ $\mathrm{S}_{\text {[anaph] }} \mathrm{V}_{\text {TENER }}$ de $\mathrm{S} 1$ como/lo que yo de $\mathrm{S} 2$ ] relies, in effect, on the construction [ $\mathrm{V}_{\mathrm{TENER}}$ $\mathrm{N} 11_{\text {[quantif] }}$ de $\mathrm{N} 2$ ], even though the quantifier preceding the preposition is generally elliptical. Thus, in the example: [...] tienes de novelista lo que yo de santo (CREA, Jose Luis Alegre Cudos, 1989 Locus amoenus) (You have of novelist that which I have of a saint $\rightarrow$ You're as much a novelist as I am a saint).

${ }^{26}$ For the difference between the meaning of the quantifying adjective poco + Adj (for example Estoy poco cansada $\rightarrow$ 'No estoy cansada') (I am little tired $\rightarrow$ I am not tired) and un poco + Adj (for example Estoy un poco cansada $\rightarrow$ 'Estoy cansada') (I am a little tired $\rightarrow$ I am tired), see Sedano (2009). In the case of poco + Adj, Bosque (1980: 27) talks of "implicit negation" through a quantifier.

${ }^{27}$ The partitive value oberved in sentences such as Tengo de todo (I have everything), No tengo nada de nada (I have nothing of nothing $\rightarrow$ I have nothing at all), No entiendo de música (I don't understand music) (see Martínez García, 2005: 195).

${ }^{28}$ For the adjectival value of some nuns used to denote qualities, see Bosque (1989: 124) and Portolés (1994: 538).

${ }^{29}$ For a detailed study of the attributive value of the verb avoir (to have) en francés, equivalent to the function of tener (to have) in Spanish, see Tellier (1992).
} 
Table 1. Semantic fields and lexical saturation of slot S2. Constructional idiom [SUBJ $\mathrm{S}_{[\mathrm{anaph}]} \mathrm{V}_{\text {[COGN] }}$ de $\mathrm{S} 1$ como/lo que yo de $\left.\mathrm{S} 2\right]$

Semantic field of S2
Disciplines related to astrophysics and aerospace science

Other branches of knowledge

Sports/games

Languages

Music

Animal reproduction

Skills

Other lexical realisation of $\mathrm{S} 2$

fisica cuántica (quantum physics)

fisica nuclear (nuclear physics)

cohetes lunares (lunar rockets/spacecraft)

ingenieria nuclear (nuclear engineering)

astrofisica (astrophysics)

mecánica cuántica (quantum mechanics)

robótica (robotics)

química subatómica (subatomic physics)

ingenieria aeroespacial (aerospace engineering)

ingenieria espacial (space engineering)

aviones (aircraft)

aeroplanos (aeroplanes)

biología marina (marine biology)

bioquímica (biochemistry)

pintura rupestre (cave paintings)

filosofia (philosophy)

economía petrolifera (the petroleum economy)

economía (economics)

medicina (medicine)

computación (computation)

ingenieria genética (genetic engineering)

abogacía (legal profession)

botánica (botany)

cirujía plástica (plastic surgery)

jeroglificos egipcios (Egyptianhieroglyphics)

trigonometría (trigonometry)

petanca (bowls)

esgrima (fencing)

polo (polo)

windsurfing (windsurfing)

póquer (poker)

hacer sudokus (to do sudokus)

golf (golf)

canicas (marbles)

papiroflexia (origami)

alemán (German)

mandarin (Mandarin)

chino (Chinese)

chino mandarin (Mandarin Chinese)

sánscrito (Sanskrit)

arameo antiguo (Ancient Aramaic)

tocar el violin (playing the violin)

canto (singing)

compositor de operas (composer of operas)

vida sexual del caracol (sexual life of snails)

vida sexual del murciélago (sexual life of bats)

vida sexual del escarabajo pelotero

(sexual life of the Dung Beetle)

vida sexual del hurón logroñés

(sexual life of the Logroño Ferret)

reproducir elefantes (to reproduce elephants)

reproducción de la mosca en el Amazonas

(the reproduction of the fly in the Amazon)

desmamar ocas (to wean geese)

calceta (knitting)

punto de cruz (cross-stitch)

comida típica nepalesa (typical food from Nepal)

cocodrilos (crocodiles)

cocina (cooking)

motores (motors)

carpinteria (carpentry)

buscar petróleo (looking for petroleum)

marcianos (Martians) 
Table 2. Grammatical category of slot $\mathrm{S} 2$. Constructional idiom [SUBJ $\mathrm{SUaph]}_{[\mathrm{C}} \mathrm{V}_{[\mathrm{COGN}]}$ de $\mathrm{S} 1$ como/lo que yo de $\left.\mathrm{S} 2\right]$

\begin{tabular}{lll}
\hline S2 & Example & Source \\
\hline nouns without a complement & {$[\ldots$. El resultado es que hoy lo dirige un burócrata } & Webcorp \\
& que de cultura sabe lo que yo de astronomia. & http://blogs.eluniversal.com.mx/ \\
& (The result is that today a beaurocrat is in charge & weblogs_detalle4939.html
\end{tabular}

nouns $\quad$ En Madrid me han tocado dependientes que sabian

modified by a complement tanto del material que vendían como yo de la vida sexual del hurón logroñés (no mucho).

(In Madrid I have come across shop assistants

who knew as much about the material that they

sold as I do about sexual life of the Logroño Ferret

(not much)).

verbs
Lo de siempre, pero esta de música clásica sabe

lo que yo de hacer sudokus, o sea, ni la menor idea. http://pensamientodisperso.blogspot.

(The same as always, but this one, about classical music, knows as much as I do about doing sudokus, that is, has not the faintest idea.)
Webcorp

http://debates.motos.coches.net/ showthread.php?128430-VisitaMOTOCARD-MALAGA

Webcorp

com.es/2010_05_27_archive.html
As also happens in slot $\mathrm{X}$ of the simple construction $\left[\mathrm{V}_{\text {TENER }} \mathrm{ADV}_{\text {[quant] }}\right.$ de $\left.\mathrm{X}\right]$, the $\mathrm{S} 1$ of the construction [SUBJ [anaph] $\mathrm{V}_{\text {TENER }}$ de $\mathrm{S} 1$ como/lo que yo de $\mathrm{S} 2$ ] can be a noun with an adjectival value. Such nouns, in addition to denoting classes of objects (the typical function of nouns) also serve to denote qualities. In all of them, the noun alludes to its referent in the role of a representative of a collection of qualities that defines an object as such and with this the meaning of the noun becomes gradable. Thus, in the following example, the noun documental acquires the value of a qualifying and gradable adjective:

\section{[...] Porque de documental tiene lo que yo de arzobispo de Zaragoza. (Webcorp: https://natsufan.wordpress.com/page/5/) \\ (Because of documentary it has that which as I of the archbishop of Zaragoza $\rightarrow$ Because it's as much a documentary as I am the archbishop of Zaragoza)}

As far as the grammatical categories of slot S2 are concerned, in Table 4 we can see that even proper nouns referring to celebrities (for example Angeline Jolie, Bill Gates) act as prototypes of a quality: Angeline Jolie of 'absolute beauty' and Bill Gates of 'absolute wealth', and therefore have an adjectival function (see above). In terms of slot S2, in Table 3 are some of the lexemes and semantic fields from the corpus examples.

With respect to the semantic fields of S2 slot, in the first place the field of religion dominates, followed by professions of a high degree of specialization and theoretical difficulty and then names of nationalities. The lexemes of slot S2 astronauta (astronaut) and cura (priest) are in a process of lexicalisation, something we can confirm thanks to the high number of occurrences found through Webcorp (more than 300 in each case). An illustration of this is that both astronauta and cura occupy slot $\mathrm{S} 2$ in the other construction analysed $\left[\mathrm{SUBJ}_{[\text {anaph] }}\right.$ $\mathrm{V}_{\text {[COGN] }}$ de $\mathrm{S} 1$ como/lo que yo de $\left.\mathrm{S} 2\right]$, despite the semantic incongruity which this supposes. An example:

- - Así seguimos escribiendo la reciente historia de esta nuestra querida España. Este Sr. me parece que de educación sabe lo que yo de cura

- (Webcorp:

http://ecodiario.eleconomista.es/politica/noticias/529 4110/11/13/Alfonso-Alonso-se-perfila-como-elsustituto-de-Wert.html)

- (- Thus we continue writing the recent history of our beloved Spain. This Mr., it seems to me, knows as much about education as I do about priests.)

The lexicalisation of the lexemes astronauta and cura as slot S2 is proof that the degree of lexical specificity of constructional idioms can vary if a slot lexicalises and becomes a (quasi) fixed constituent. Thus, in light of the data drawn from the corpus, we see that the comparata lo que yo/como yo de astronauta (that which I/as I (know/am) of astronauts) and lo que yo/como yo de cura (that which I/as I (know/am) of priests) are becoming lexical helpers for the comparatum of the comparative constructional idiom [SUBJ $\mathrm{SUnaph} \mathrm{V}_{\mathrm{TENER}}$ de $\mathrm{S} 1$ como/lo que yo de S2]. This phenomenon can also be confirmed as occurring between comparative idioms, for example by the comparatum Carracuca in the comparative idioms más feo que Carracuca, más listo que Carracuca, más viejo que Carracuca (uglier than Carracuca $\rightarrow$ very ugly; smarter than Carracuca $\rightarrow$ very smart; older than Carracuca $\rightarrow$ very old) (see García-Page Sánchez, 2008a: 322). 
Table 3. Lexical saturation of slot S2. Constructional idiom [SUBJ $\mathrm{S}_{\text {[anaph] }} \mathrm{V}_{\mathrm{TENER}}$ de $\mathrm{S} 1$ como/lo que yo de $\left.\mathrm{S} 2\right]$

\begin{tabular}{ll}
\hline Semantic field of slot S2 & Lexical Realisation of slot S2
\end{tabular}

cura (priest)

monja (nun)

monja ursulina (Ursuline nun)

monja clarisa (Poor Clare nun)

monja de clausura (cloistered nun)

monja carmelita descalza (Barefoot Carmelite nun)

santa/santo (saint)

monje budista (Buddhist monk)

monje (monk)

papa (Pope)

papa de la Iglesia Católica (Pope of the Catholic Church)

arzobispo (archbishop)

arzobispo de Zaragoza (Archbishop of Zaragoza)

obispo de Cuenca (Bishop of Cuenca)

obispo de Sigüenza (Bishop of Sigüenza)

cristiano (Christian)

sacerdote (priest)

rabino ortodoxo (Orthodox rabbi)

mahometano (Mohammedan)

beato (blessed)

apóstol (apostle)

Professions related to space, physics, chemistry

mayordomo de cofradia (butler of the brotherhood)

astronauta (astronaut)

físico nuclear (nuclear physicist)

astrofisico (astrophysicist)

ingeniero aerotécnico de la Nasa

(NASA aero-technical engineer)

ingeniero/ingeniera (engineer)

ingeniero nuclear (nuclear engineer)

químico (chemist)

astrólogo (astrologer)

piloto de las Fuerzas Aéreas de los Estados Unidos de América (pilot of the Air Forces of the United States of America)

Professions related to music and dance

cantante (singer)

cantante lírica holandesa (Dutch lyric singer)

compositor (composer)

gaitero (bagpiper)

lagarterana (traditionally dressed woman from Lagartera)

bailarina de ballet (ballet dancer)

Other professions

bombero (fire fighter)

torero (bull fighter)

lechero (dairyman)

fontanero (plumber)

diplomática (diplomat)

cabaretera (showgirl)

cocinera (cook)

cardiólogo (cardiologist)

chulo putas (pimp of whores)

maestro cervecero (master brewer)

pintora (painter)

jardinero (gardener)

periodista (journalist)

pastelera (cake maker)

submarinista (submariner)

guerrero bantú (Bantu warrior)

Nationalities (ethnic)

chino/china (Chinese)

japonés/japonesa (Japanese)

alemán/alemana (German)

finlandés (Finnish)

rusa (Russian)

irlandesa (Irish)

sueco (Swedish)

jamaicano (Jamaican)

senegalés (Senegalese)

suizo (Swiss)

judio (Jewish)

indio (Indian) 
Table 3. Continue

Wealth

\section{EXTRA-TERRES-TRIAL INHABI-TANTS}

FAMOUS PEOPLE

POSITIVE PHYSICAL AND PSYCHO-LOGICAL CHARACTE-RISTICS

\section{SeXual STATE}

TYPE OF SPORTSPER SON OTHERS

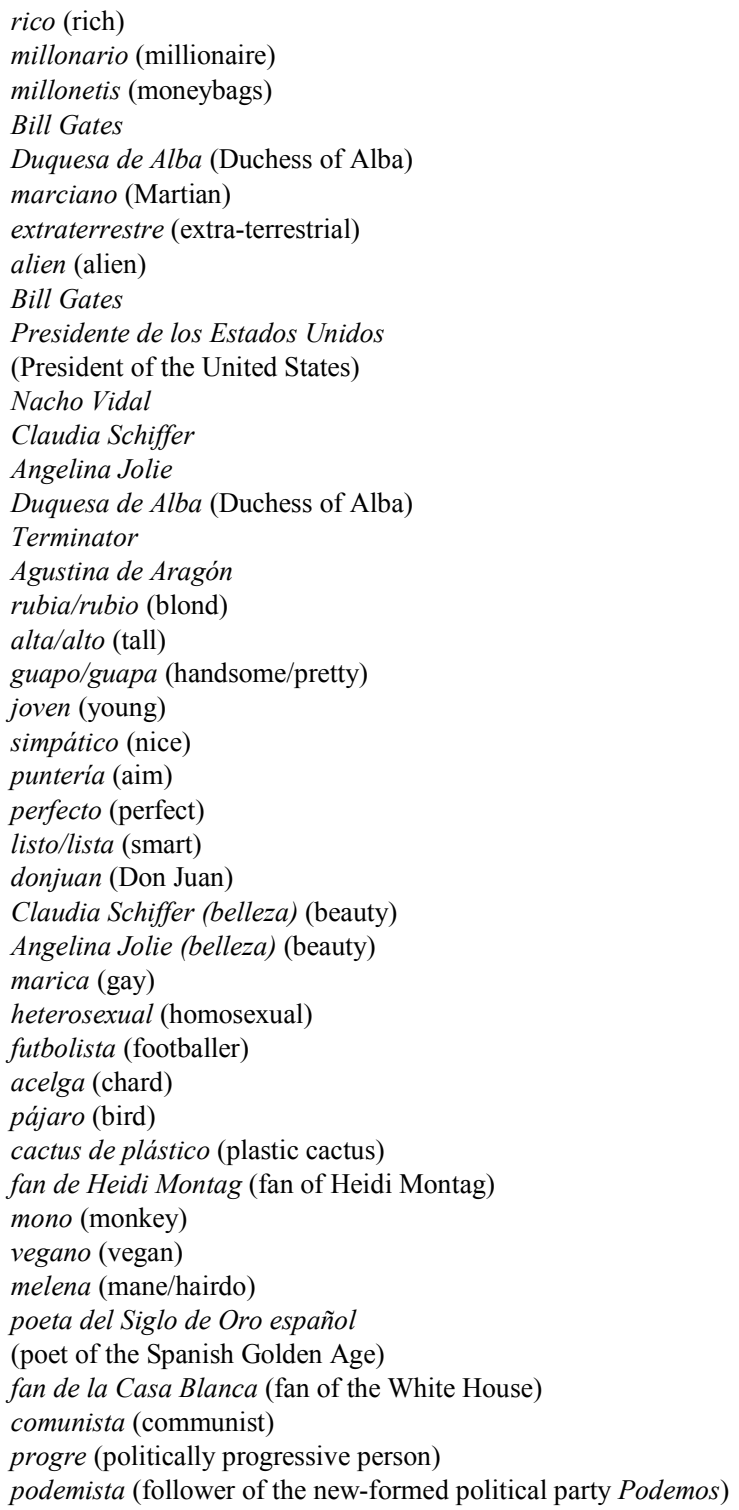

Table 4. Grammatical category of slot $\mathrm{S} 2$. Constructional idiom [SUBJ ${ }_{[a n a p h]} \mathrm{V}_{\mathrm{TENER}}$ de $\mathrm{S} 1$ como/lo que yo de $\mathrm{S} 2$ ]

\begin{tabular}{|c|c|c|}
\hline $\mathrm{S} 2$ & Example & Source \\
\hline Adjectives & $\begin{array}{l}\text { Tiene buena pinta, ahora, ese potaje tiene } \\
\text { de canario lo que yo de ruso. (It looks } \\
\text { good, now, that stew is as much from } \\
\text { the Canary islands as I am Russian.) }\end{array}$ & $\begin{array}{l}\text { Webcorp: } \\
\text { http://blogs.libertaddigital. } \\
\text { com/blog-appetit/potaje-canario- } \\
\text { de-karlos-arguinano/ }\end{array}$ \\
\hline Nouns of an adjectival value & $\begin{array}{l}\text { El médico de Greysi Ulloa tiene de cirujano } \\
\text { lo que yo de periodista. (Greysi Ulloa's } \\
\text { doctor is about as much a surgeon as } \\
\text { I am a journalist.) }\end{array}$ & $\begin{array}{l}\text { Webcorp } \\
\text { http://www.netjoven.pe/espectaculos/169358/ } \\
\text { Peluchin-El-medico-de-Greysi- Ulloa-tiene-de } \\
\text {-cirujano-lo-que-yo-de-periodista.html }\end{array}$ \\
\hline $\begin{array}{l}\text { Nouns of an adjectival } \\
\text { value with a prepositional } \\
\text { complement }\end{array}$ & $\begin{array}{l}\text { Jaja jajjjaja, de Volvo los Ford tienen lo } \\
\text { que yo de piloto de las Fuerzas Aéreas de los } \\
\text { Estados Unidos de América... (Haha hahaha, } \\
\text { Fords are as much (like) Volvos as I am pilot of } \\
\text { the Air Forces of the United States of America...) }\end{array}$ & $\begin{array}{l}\text { Webcorp } \\
\text { http://www.coches.net/opiniones/ } \\
\text { nuevo-ford-cmax-grand-cmax }\end{array}$ \\
\hline Proper nouns & $\begin{array}{l}\text { De mago tiene lo que yo de Bill Gates. } \\
\text { (He's as much a magician as I am Bill Gates.) }\end{array}$ & $\begin{array}{l}\text { Webcorp: } \\
\text { http://m.forocoches.com/ } \\
\text { foro/showthread.php?t=3434340 }\end{array}$ \\
\hline
\end{tabular}




\section{Semantic and Pragmatic Aspects of Antiphrasis- Based Comparative Constructional Idioms}

The constructions studied here constitute a form of implied negation ${ }^{30}$ (Bosque, 1980), since the negation does not appear explicitly in the utterance, unlike that which does indeed happen in other idioms of negative polarity, such as iNi hablar! (Don't even talk about it!), ¡De eso nada! ((Let's say) nothing about this!) (see García-Page Sánchez, 1998). The antiphrasis needs a conceptual detour in order to be encoded and decoded, that is, instead of choosing the simple formula of negation, the speaker opts for a complicated paraphrase in which the qualities of two different subjects are compared. In Glovňa's (1992: 55) opinion, in relation to antiphrasis-based comparative idioms, "[k]ompliziertere sprachliche Bilder (in unserem Fall mit ironischer Komponente) dienen den semantischen, pragmatischen, vor allem den semiotischen Zielen der Kommunikation." ${ }^{\prime 31}$, that is, the paraphrasis in the form of an antiphrasis has a clearly pragmatic function, that of reinforcing the expressivity of the message and of being more convincing for the receiver. Likewise, the fact that the speaker chooses himself as part of the comparatum in the antiphrasis-based comparative constructional idioms lends these an epistemic modal value, because with them the speaker reinforces his degree of certainty with respect to the proposal issued. We would, in this way, find ourselves looking at an evidential construction par excellence: the speaker sets himself up as a guarantor of the comparison and as a source of clear information for the interlocutor. In the words of Albelda Marco (2007: 32), in the intensification of the epistemic modality, "[a]1 señalar explícitamente que algo es evidente se refuerza la expresión de su verdad" ${ }^{32}$.

At the same time, these evidential constructional idioms also carry a high degree of the speaker's subjectivity, as Torrent (2013: 215) notes in relation to the idioms created from objective-evidential lexemes: "Our thesis in this regard is that objectiveevidential lexemes or objective-evidential constructions have given rise to evidential idioms that express a high degree of subjectivity." With this strong subjectivity, coupled with a clear commitment to truth, the speaker aims to strengthen the intrinsic negative polarity to the antiphrasis and successfully

\footnotetext{
${ }^{30}$ In accordance with what Ruiz Gurillo (2009: 379) claims in relation to ironic idioms, we believe that the implicit negation of antiphrasis-based constructional idioms represents the grammaticalisation of a conversational implicature.

31 The complex linguistic images (in our case with an ironic component) are available for the semantic, pragmatic and above all semiotic aims of communication (our translation).

32 [B]y signalling explicitly that something is evident the expression of its truth is reinforced(our translation).
}

achieve his communicative intention of disagreement and criticism. These expectations explain why the speaker, against the law of economy of language, does not choose the most direct route of explicit negation and opts for a conceptual and formal detour. In the words of Boyer (2000: 201):

\begin{abstract}
"L'antiphrase-de même que la périphrase- a quelque chose de fascinant car elle va contre la tendance naturelle de la langue á l'économie : pourquoi dire le contraire de ce qu'on veut laisser entendre alors qu'il est si simple de le dire sans détours?"’3
\end{abstract}

A further pragmatic characteristic of these constructions is the humorous effect that they provoke in the hearer: especially so through the lexeme of slot N2 which alludes to exaggerated or eccentric images ${ }^{34}$, for example la vida sexual del escarabajo pelotero, la vida sexual del hurón logroñés, reproducir elefantes, la reproducción de la mosca en el Amazonas (the sexual life of the Dung Beetle, the sexual life of the Logroño Ferret, to reproduce elephants, the reproduction of the fly in the Amazon), the speaker succeeds humorously in winning over the listener. Humour is taken to an extreme point when through comparison a negative image of the speaker is implied, be it in relation to his or her physical appearance of intellectual capacity:

- Estos de secta tienen lo que yo de guapo,
nada.
(Webcorp: https://es-
la.facebook.com/ValorPorMichoacan/posts/14
79179835630009)
(-These are about as much a sect as I
amhandsome, not at all.)

- Estos muñecos de gengibre tienen de gengibre lo que yo de rubia... vamos, nada!! (Webcorp: http://www.gotblogger.com/dulcetopia/?p=71)

(- These gingerbread men have as much ginger as I have blondness... that is, nothing!)

The evaluative adjectives that the speaker tends to use to create a negative image of himself are: rubia,

\footnotetext{
33 The antiphrasis -as with the periphrasis- has something fascinating about it because it goes against language's natural tendency for economy : why say the opposite of what you want to convey when it is so simple to say it without a detour? (our translation)

${ }^{34}$ In the opinion of Moreira Flores (2004: 229), the stranger and more absurd the image on which the comparison of the comparative idioms relies, the greater the expressivity and polarity of the meaning obtained.
} 
rubio, guapo, alto, listo (blond, good looking, tall, smart), which are implicitly negated through the constructional idiom. From a pragmatic point of view, the speaker uses this resource of humorous self-criticism to give a "hyper-real" and quite negative image of himself or herself. With this tactic of self-ridicule, the speaker intends to strategically win over the interlocutor and convince them of his position. Another effect which is achieved is strengthening the commitment to truth in the utterance and intensifying his or her positive face with respect to the interlocutor (Hessky, 1987: 13) ${ }^{35}$.

A fundamental aspect of these constructions is their echoing function, which manifests itself in the anaphoric value of the subject and of slot S1. For this reason, the prototypical use of these constructional idioms is a dialogue kind of speech in which the speaker, in his speaking turn, uses the construction to show disagreement, criticism and/or rejection with respect to some previous aspect of the discourse. Through this echoing character, the realisation of the subject with the deictic form ese (that) (with a derogatory value) is frequent. Also, slot S1 of the construction includes a previously named attribute (dictum), which through the construction is negated in an absolute degree by the speaker. As occurs in other echoing constructions, the construction allows the speaker to show his opinion, demonstrating "el valor básico de desacuerdo con su interlocutor y, adicionalmente, los de rechazo, descrédito o incredulidad" (the basic value of disagreement with his partner and, in addition, those of rejection, discredit or disbelief) (see Mura and Ruiz Gurillo, 2010: 52). Given its echoing value of reply, these constructions constitute interesting structures to be studied from the point of view of speech turns in conversation (see Mura, 2014: 286):

"En suma, pues, los esquemas fraseológicos (en concreto, los que expresan desacuerdo) también se pueden explicar y justificar como alternancia de turnos, esto es, representan unidades sociales del análisis de la conversación $[\ldots] . " 36$

As we have already mentioned, the fundamental illocutionary component of these constructions,

\footnotetext{
35 It is worth recalling here that these antiphrasis-based constructions constitute an attack to the positive face of the interlocutor. Indeed, Boyer (2000: 201-203) talks of the "hostility" and "aggression" of antiphrastic expressions, in that they are based on mockery of the person or thing which is the object of comparison.

36 In sum, therefore, phraseological schemata (specifically, those that express disagreement) can also be explained and justified as the alternation of turns, that is, they represent social units of analysis of the conversation [...]. (our translation).
}

intrinsic to their use, is that of Disagreement ${ }^{37}$, which can be seen very clearly in the following example:

- Quién sabe-discurrió Marchena, arrugando la frente-.Quizá en la viuda tengas un hilo para tirar del ovillo.

- Vamos, Marchena-protesté-. Si esto es lo que parece, la viuda debe de saber tanto del asunto como yo de jugar al polo. (CREA, Lorenzo Silva, 2000: El alquimista impaciente)

- (- Who knows-Marchena reasoned, furrowing her brow. Perhaps in the widow you might have a thread to pull from the ball (of thread)

- (- Come on, Marchena-I complained. If this is what it seems, the widow must know as much about the topic as I do about playing polo.)

As can be appreciated in this example, these constructions become an echo of information contained, either implied or explicitly, in the prior discourse, with the aim of refuting it and presenting it as its polar opposite, affording the speaker a maximum degree of certainty. ${ }^{38}$ As we have noted above, the prototypical discoursive form of these constructions is that of dialogue. The textual typology of the corpus examples ranges from novels and theatre (examples of feigned orality) to blogs, forums and comments from readers in digital newspapers.

The stylistic register is colloquial, even vulgar in some cases. In the examples taken from forums, blogs and readers' comments (which together constitute 85\% of our corpus), after the construction there can appear an explicative tag of the type nada (nothing), es decir, bien poco (that is, in fact nothing), which strengthens the negation (see above). Also frequently used to intensify the jocular tone and humour are the onomatopoeia jaja (ha-ha) and jeje (ha-ha), as in the example Este tiene de macho alfa lo que yo de astronauta...jajaja. (This guy is about as much an alpha male as I am an astronaut... hahaha) $)^{39}$. On occasion, the constructions appear in the form of direct discourse in interviews or headlines, as in the following example from the newspaper El Pais:

\footnotetext{
37 As claimed by Van Lancker et al. (2012: 98), “[n]ative speakers know the schema's stereotyped form (including its prosody), conventional meaning, and the guidelines of pragmatic use".

38 Sometimes they simultaneously achieve a cataphoric function, when the negative quality is explained further on in the text. In this way, these constructions can act as a pivot between information previously cited (or presupposed) and information which develops further on in the text.

$39<\mathrm{http} / / /$ www.larazon.es/detalle_normal/noticias/8011276/taniasanchez-recibio-un-piso-de-proteccion-que-vendio-al-portavozde-iu-en-rivas\#.Ttt17M5M4DYExHA>.
} 
Anasagasti: "La ministra sabe de fútbol lo que yo de toros."

(Webcorp:

http://elpais.com/diario/1998/09/10/deportes/9 05378402_850215.html)

(Anasagasti: "The minister knows about football that which I (do) about bulls.")

\section{Conclusion}

This empirical study, based on our own corpus, has confirmed the initial hypothesis on the constructional character of the structures $\left[\mathrm{SUBJ}_{[\text {anaph] }} \mathrm{V}_{\mathrm{TENER}}\right.$ de $\mathrm{S} 1$ como/lo que yo de $\mathrm{S} 2]$ and $\left[\mathrm{SUBJ}_{[\text {anaph] }} \mathrm{V}_{\text {[COGN] }}\right.$ de $\mathrm{S} 1$ como/lo que yo de S2], under the following characteristics:

- The constructions possess some fixed constituents and some variable ones (free slots), which are realised in discourse through different lexemes

- They possess an intensifying meaning of negative polarity ('absolutely nothing'), derived from their antiphrastic structure, as with the pragmatic meaning disagreement or criticism, associated with their echoing value

- Within their heterogeneity, the lexemes which realise slot $\mathrm{S} 2$ in discourse can be semantically systemised

- Tendencies are observed for the lexicalisation of certain nouns in slot $\mathrm{S} 2$, which strengthen the thesis that constructional idioms are intermediate structures within a scale of grammar-lexis which with use can reach the lexical pole, thus gaining lexical specificity. It can also happen that constructional idioms move close to the grammatical pole and lose lexical specificity

From a pragmatic point of view, the constructional idioms [SUBJ ${ }_{\text {[anaph] }} \mathrm{V}_{\mathrm{TENER}}$ de $\mathrm{S} 1$ como/lo que yo de $\mathrm{S} 2$ ] and $\left[\mathrm{SUBJ}_{\text {[anaph] }} \mathrm{V}_{\text {[COGN] }}\right.$ de $\mathrm{S} 1$ como/lo que yo de $\left.\mathrm{S} 2\right]$ show a clear epistemic modal value through the explicit appearance of yo $(I)$ speaker in the comparatum, which strengthens the truth value of the utterance and the commitment of the speaker to the propositional content. Finally, they show an echoing value in response to a previous proposition. This value is seen in the anaphoric function of the subject of the construction and in the implicit or explicit reference to the prior discourse through slot S1.

\section{Acknowledgement}

This paper is dedicated to the professors Wolfgang Fleischer (Leipzig University) in memoriam, Dmitrij Dobrovol'skij (Russian Language Institute, Russian
Academy of Sciences) and Gloria Corpas (Málaga University) for their great and innovative work in the field of Phraseology.

\section{Funding Information}

The present research has been financed by the Spanish Ministry of Economy and Competitiveness, grant FFI2013-45769-P (Combinaciones fraseológicas del alemán de estructura [Prep. + Sust.]: patrones sintagmáticos, descripción lexicográfica y correspondencias en español).

\section{Ethics}

The author hereby declares that there is not any ethical issue or conflict of interest arising from the present article or the research on which it is based.

\section{References}

Albelda Marco, M., 2007. La intensificación como categoría pragmática: revisión y propuesta: una aplicación al español coloquial. 1st Edn., Peter Lang, New York, ISBN-10: 363156452X, pp: 242.

Bosque, I., 1980. Sobre la negación. 1st Edn., Ediciones Catedra, Spain, ISBN-10: 8437602513, pp: 171.

Bosque, I., 1989. Las categorías gramaticales. Madrid: Síntesis. ISBN-10: 9788477380757.

Boyer, D., 2000. Les antiphrases lexicalisées en français et en espagnol-essai de typologie comparée et problèmes de traduction. Société des Hispanistes Français.

Burger, H., 2010. Phraseologie. Eine Einführung anhand des Deutschen. Schmidt, Berlin.

Černyševa, I.I., 1975/2005. Phraseologie. In: Lexikologie der deutschen Gegenwartssprache, Stepanova, M.D. and I.I. Černyševa, (Eds.), 2nd End., 1986, Akademia, Moskau, ISBN-10: 5-7695-2310-7, pp: 198-261.

Corpas Pastor, G., 2013. Detección, descripción y contraste de las unidades fraseológicas mediante tecnologías lingüísticas. In: Fraseopragmática, Olza, I. and E. Manero, (Eds.), Frank and Timme, Berlin, ISBN: 10- 978-3-86596-448-9, pp: 335-373.

Corpas Pastor, G., 2014. El fraseólogo internauta: cómo pasarlo pipa en la red. In: Fraseología y paremiología: enfoques y aplicaciones, Durante, V., (Eds.), Instituto Cervantes, Madrid,

ISBN-10: 978-84-697-0320-5, pp: 133-152.

De Knop, S. and F. Mollica, 2013. Die Konstruktionsgrammatik für die Beschreibung romanischer Sprachen. In: Konstruktionsgrammatik in den romanischen Sprachen, De Knop, S., F. Mollica and J. Kuhn (Eds.), Peter Lang, ISBN-10: 3631622694, pp: 9-23. 
Deppermann, A., 2006. Construction Grammar-eine Grammatik für die Interaktion?. In: Grammatik und Interaktion, Deppermann, A. (Eds.,), Verlag für Gesprächsforschung, Radolfzell, pp: 43-66.

Dobrovolskij, D. and E. Piirainen, 2009. Zur Theorie der Phraseologie: Kognitive und kulturelle Aspekte. 1st Edn., Stauffenburg Verlag, German, ISBN-10: 3860571796,

Dobrovol'skij, D.O., 1988. Phraseologie als Objekt der Universalienlinguistik. 1st Edn., Verlag Enzyklopädie, Leipzig, ISBN-10: 3324002990, pp: 264

Dobrovol'skij, D., 2011. Phraseologie und Konstruktionsgrammatik. In: Konstruktionsgrammatik III. Aktuelle Fragen und Lösungsansätze, Lasch, A. and A. Ziem (Eds.), Stauffenburg, Tübingen, ISBN-10: 3860571966, pp: 111-130.

Dobrovol'skij, D., 2012. Phrasem-Konstruktionen in Parallelcorpora. In: Idiome, Konstruktionen, 'verblümte rede', Prinz. $M$ and $U$. RichterVapaatalo, (Eds.), Hirzel, Stuttgart, ISBN-10: 3777621447, pp: 302-316.

Donalies, E., 2009. Basiswissen Deutsche Phraseologie. 1st Edn., UTB GmbH, Tübingen, ISBN-10: 3825231933, pp: 126.

Eckert, R., 1979. Aspekte der konfrontativen Phraseologie. Linguistische Studien, Reihe A, Arbeitsberichte, 57: 74-80.

Feilke, H., 1994. Common sense-Kompetenz: Überlegungen zu einer Theorie des "sympathischen" und "natürlichen" Meinens und Verstehens. 1st Edn., Suhrkamp, Frankfurt am Main Suhrkamp, ISBN-10: 3518581708, pp: 422.

Feilke, H., 1996. Sprache als soziale Gestalt: Ausdruck, Prägung und die Ordnung der sprachlichen Typik. 1st Edn., Suhrkamp, Frankfurt am Main, ISBN-10: 3518582356, pp: 363.

Fillmore, C.J., P. Kay and M. C. O’Connor. 1988 Regularity and idiomaticity in grammatical constructions: The case of let alone. Lang., 64: 501-538.

Finkbeiner, R., 2008. Idiomatische Sätze im Deutschen: syntaktische, semantische und pragmatische Studien und Untersuchung ihrer Produktivität. 1st Edn., Acta Universitatis Stockholmiensis, Stockholm, ISBN-10: 9185445959, pp: 294.

Fischer, K., 2006. Konstruktionsgrammatik und Interaktion. In: Konstruktionsgrammatik I: Von der Anwendung zur Theorie, Fischer, K. and A. Stefanowitsch (Eds.), Stauffenburg, Tübingen, ISBN-10: 3860577883, pp: 129-146.

Fleischer, W., 1997. Phraseologie der deutschen Gegenwartssprache. 2nd Edn., Niemeyer, Tübingen Niemeyer, ISBN-10: 3484730323, pp: 299
García-Page Sánchez, M., 1998. Expresiones fijas de polaridad negativa. LEA: Lingüística Española Actual, 20: 55-78.

García-Page Sánchez, M., 2007. Esquemas sintácticos de formación de locuciones adverbiales. Moenia: Revista lucense de lingüistica and literatura, 13: 121-144.

García-Page Sánchez, M., 2008a. Introducción a la fraseología española: estudio de las locuciones. 1 st Edn., Anthropos, Rubí, ISBN-10: 8476588674, pp: 527.

García-Page Sánchez, M., 2008b. La comparativa de intensidad: la función del estereotipo. Verba, 35: 143-178.

Glovňa, J., 1992. Ironische phraseologische Vergleiche. In: Die Phraseologie als Intensivierungsfaktor der Kommunikation, Krošláková, E., (Eds.), Pedagogická fakulta, Nitra, ISBN-10: 39082590, pp: 51-56.

Goldberg, A.E., 1995. Constructions: A construction grammar approach to argument structure. 1st Edn., University of Chicago Press, Chicago, ISBN-10: 0226300862, pp: 265.

Goldberg, A.E., 2006. Constructions at Work: The Nature of Generalization in Language. 1st Edn., Oxford University Press, Oxford, ISBN-10: 0199268517, pp: 280.

González Rey, M. I., 2000. La presencia de la comparación en la construcción de expresiones idiomáticas del español y del francés. Cahiers du P.R.O.H.E.M.I.O., 3: 213-228.

Häusermann, J., 1977. Phraseologie. Hauptprobleme der deutschen Phraseologie auf der Basis sowjetischer Forschungsergebnisse. 1st Edn., M. Niemeyer, Tübingen, ISBN-10: 3112177231, pp: 134.

Hessky, R., 1987. Objektives und Subjektives im phraseologischen Vergleich. Zur Struktur und Semantik phraseologischer Vergleiche. Germanistisches Jahrbuch DDR-UVR, VI. Jahrgang: 193-204.

Hummel, M., 2012. Polifuncionalidad, polisemia y estrategia retórica: Los signos discursivos con base atributiva entre oralidad y escritura. 1st End., de Gruyter, Berlin, ISBN-10: 3110281244, pp: 446.

Hundt, C., 2005. Komparative Phraseologismen im Sprachvergleich Portugiesisch-Deutsch. In: Beiträge zum romanisch-deutschen und innerromanischen Sprachvergleich, Schmitt, C. and B. Wotjak, (Eds.), Romanistischer Verlag, Bonn, ISBN-10: 3861431637, pp: 127-145.

Kay, P. and C.J. Fillmore, 1999. Grammatical constructions and linguistic generalizations: The What's X doing Y? construction. Language, 75: 1-33. 
Kleinberger Günther, U., 2006. Phraseologie und Sprichwörter in der digitalen Öffentlichkeit-am Beispiel von Chats. In: Phraseology in Motion I. Methoden und Kritik, Häcki Buhofer, A. and H. Burger, (Eds.), Schneider Verlag Hohengehren, Baltmannsweiler, ISBN-10: 3834001007, pp: 229-243.

Koch, P. And W. Österreicher, 1985. Sprache der Nähe Sprache der Distanz. Mündlichkeit und Schriftlichkeit im Spannungsfeld von Sprachtheorie und Sprachgeschichte. Romanistisches Jahrbuch, 36/85: 15-43.

Konecny, C., 2010. Lexikalische Kollokationen und der Beitrag der Internet-Suchmaschine Google zu ihrer Erschließung und Beschreibung. In: Korpora, Web und Datenbanken. Corpora, Web and Databases: Computergestützte Methoden in der modernen Phraseologie und Lexikographie. Computer-Based Methods in Modern Phraseology and Lexicography, Ptashnyk, S., E. Hallsteinsdóttir and N. Bubenhofer, (Eds.), Schneider Verlag Gmbh, ISBN-10: 3834007331, pp: 77-94.

Lausberg, H., 1984. Manual de retórica literaria: Fundamentos de una ciencia de la literatura. 1st Edn., Gredos, Madrid. ISBN-10: 8424911466.

Lázaro Carreter, F., 1971. Diccionario de términos filológicos. 3rd Edn., Gredos, Madrid, pp: 443.

Durán, J.D.D.L. and A.P. Bertrán, 2005. Las comparaciones proverbiales en inglés. Una aproximación tipológica y traductológica. In: La creatividad en el lenguaje: colocaciones idiomáticas y fraseología, Durán, J.D.D.L. and A.P. Bertrán, (Eds.), Granada Lingvistica, Granada, ISBN-10: 847933312X, pp: 381-397.

Martínez García, H., 2005. Estructura y cuantificación partitiva. Archivum: Revista de la Facultad de Filología, 57: 169-195

Mellado Blanco, C., 2009. Intensivierung durch Vergleich im Deutschen und Spanischen: Eine Strukturen- und Bedeutungsanalyse. In: Phraseologie disziplinar und interdisziplinär, Földes, C. (Eds.), Narr, Tübingen, ISBN-10: 3823365347, pp: 465-476.

Mellado Blanco, C., 2012, Las comparaciones fijas en alemán y español: algunos apuntes contrastivos en torno a la imagen. 1st Edn., Linred: Lingüística en Red, 10: 1-32.

Mellado Blanco, C., 2013. Tipología de la motivación fraseológica en un corpus onomasiológico alemánespañol. In: Fraseología, Opacidad y Traducción, Mogorrón Huerta, P., D. Gallego Hernández, P. Masseau and M. Tolosa Igualada, (Eds.), Peter Lang, Berlin, ISBN-10: 978-3-631-62572-9, pp: 39-65.
Mellado Blanco, C., 2015a. El valor de "construcción" de los somatismos reflexivos de daño físico en alemán y la búsqueda de equivalencias en español. In: Certas Palavras não Leva o Vento, SelmaMonteiro-Plantin, R. (Ed.), Parole, Fortaleza, ISBN-10: 978-67247-02-1, pp: 85-108.

Mellado Blanco, C., 2015b. Phrasem-Konstruktionen und lexikalische Idiom-Varianten: der Fall der komparativen Phraseme des Deutschen. In: Argumentstruktur - Valenz - Konstruktionen, Engelberg, S., M. Meliss, K. Proost and E. Winkler (Eds.), Narr,Tübingen. ISBN-10: 978-3-8233-6960-8.

Millán, J.A., 2002. El mundo entero le saldrá al encuentro. Las comparaciones en sus repertorios. In: Language dictionaries. Studies offered to Manuel Seco, Miranda, P.A.D. and J.P. Polo, ISBN-10: 84-7635-537-8, pp. 183-197.

Montoro del Arco, E.T., 2008. El concepto de locución con casillas vacías. In: Colocaciones y fraseología en los diccionarios, Mellado Blanco, C. (Eds.), Peter Lang, Frankfurt am Main, ISBN-10: 3631574215, pp: 131-146.

Moreira Flores, C.M., 2004. Zum Ausdruck des höchsten Grades im Deutschen und im Portugiesischen.

Mura, G.A., 2014. Español coloquial y fraseología: los esquemas fraseológicos como unidades de la conversación. Estudios de Lingüística del Español, 35: 297-287.

Mura, A. and L. Ruiz Gurillo. 2010. De la construcción a la fórmula: estudio contrastivo de un esquema fraseológico en español e italiano. Cuadernos de Filología Italiana, 17: 47-64.

Mura, G.A., 2012. La fraseología del desacuerdo: Los esquemas fraseológicos en español y en italiano. Universidad Complutense de Madrid.

Olza Moreno, I., 2011. ¡Qué fraseología ni qué narices! Fraseologismos somáticos del español y expresión del rechazo metapragmático". In: Paremiología y herencia cultural, Pamies Bertrán, A., J. Luque Durán and P. Fernández Martín (Eds.), Granada Lingvistica, Granada, ISBN-10: 8492782579, pp: 181-191.

Ortega Ojeda, G., 1990. Comparaciones estereotipadas y superlatividad. In: Congreso de la Sociedad Española de Lingüística, Álvarez Martínez, M.A. (Eds.), Gredos, Madrid, ISBN-10: 8424914376, pp: 729-737.

Pamies Bertrán, A. 2005. Comparación estereotipada y colocación en español y francés. In: La creatividad en el lenguaje: colocaciones idiomáticas y fraseoligía, Luque Durán, J.D.D. and A. Pamies Bertrán (Eds.), Granada Lingvistica, Granada, ISBN-10: 847933312X, pp: 469-484. 
Penadés Martínez, I., 1999. Para un tratamiento lexicográfico de las expresiones fijas irónicas desde la Pragmática. Pragmalingüística, 7: 185-210.

Penadés Martínez, I., 2010. Las construcciones comparativas en los diccionarios fraseológicos. In: La lexicografía en su dimensión teórica, Castillo Carballo, M.A. and J.M. García Platero, (Eds.), Servicio de Publicaciones, Málaga, ISBN-10: 978-84-9747-297-5 pp: 473-494.

Portolés Lázaro, J., 1994. La metáfora y la lingüística: los atributos metafóricos con un enfático. In: Gramática del español, Demonte, V., (Ed.), El Colegio de México, México, ISBN-10: 968-12-0599-5, pp: 531-556.

Ruiz Gurillo, L., 2009. La gramaticalización de unidades fraseológicas irónicas. In: Dime cómo ironizas y te diré quién eres: Una aproximación pragmática a la ironía, Ruiz, L. and X.A. Padilla García, (Eds.), Peter Lang, New York, ISBN-10: 3631581297, pp: 371-390.

Schemann, H., C. Mellado Blanco, P. Buján, N. Iglesias and J.P. Larreta et al., 2013. Idiomatik DeutschSpanisch. Buske, Hamburg. ISBN-13: 978-3-87548-628-5.

Schindler, W., 1993. Phraseologismen und Wortfeldtheorie. In: Studien zur Wortfeldtheorie, Rolf Lutzeier, P., (Eds.), M. Niemeyer, Tübingen, ISBN-10: 3484302887, pp: 87-106.

Sedano, M., 2009. poco/un poco + Adjetivo: diferencias semánticas y consecuencias distribucionales. Universidad Central de Venezuela, 21: 151-179.

Staffeldt, S., 2011. In der Hand von Konstruktionen. Eine Fallstudie zu bestimmten Phraseologismen mit in ... Hand. In: "Konstruktionsgrammatik III. Aktuelle Fragen und Lösungsansäze", Lasch, A. and A. Ziem, (Eds.), Stauffenburg, pp: 131-148.

Stathi, K., 2011. Idiome in der Konstruktionsgrammatik: im Spannungsfeld zwischen Lexikon und Grammatik. In: Konstruktionsgrammatik III. Aktuelle Fragen und Lösungsansätze, Lasch, A. and A. Ziem (Eds.), Stauffenburg, Tübingen, ISBN-10: 3860571966, pp: 149-163.
Stein, S., 2007. Mündlichkeit und Schriftlichkeit aus phraseologischer Perspektive. In: Phraseologie: ein internationales Handbuch zeitgenössischer Forschung, Burger, H., D. Dobrovol'skij, P. Kühn and N.R. Norrick, (Eds.), Walter de Gruyter, New York, ISBN-10: 3110190761, pp: 220-236.

Steyer, K., 2013. Usuelle Wortverbindungen: Zentrale Muster des Sprachgebrauchs aus korpusanalytischer Sicht. 1st Edn., Narr, Tübingen, ISBN-10: 3823368060, pp: 390.

Taylor, J.R., 2014. Cognitive linguistics (for Routledge Handbook of Linguistics), draft. 2014Cognitive_linguistics_for_RoutledgHandbook_ of_Linguistics.

Tellier, C., 1992. Remarques sur avoir attributif et possessif. Revue québécoise de linguistique, 22: 165-181.

Torrent, A., 2013. Evidentiality, subjectivity and grammaticalisation: Spanish idioms and their German translation. Romanistik in Geschichte und Gegenwart, 19: 215-229.

Van Lancker Sidtis, D., K.M. Kougentakis, K. Cameron, C. Falconer and J.H. Sidtis, 2012. Down with -: The linguistic schema as intermediary between formulaic and novel expressions. Yearbook of Phraseology, 3: 87-107.

Zamora Muñoz, P., 2003. Esquemas sintácticos fraseológicos pragmáticos. In: Homenaje al profesor Estanislao Ramón Trives, Almela Pérez, R., D.A. Igualada Belchí, J.M. Jiménez Cano and A. Vera Luján, (Eds.), Universidad de Murcia, Murcia, ISBN-10: 84-8371-471-X, pp: 825-836.

Zuluaga, A., 1980. Introducción al estudio de las expresiones fijas. 1st Edn., P.D. Lang, Frankfurt a.M., Bern, ISBN-10: 3820464409, pp: 278. 